REVIEW ARTICLE

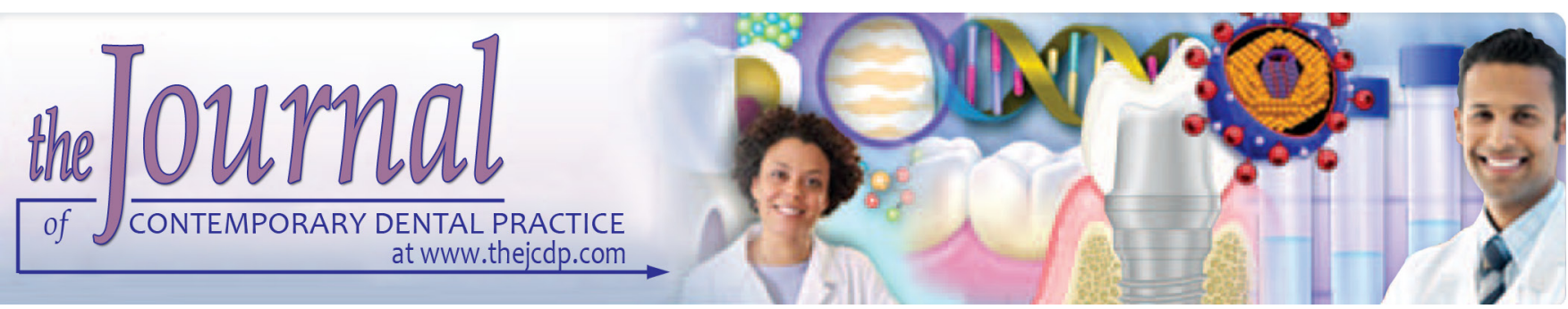

\title{
Establishing Apical Patency: To be or not to be?
}

\author{
'Zahed Mohammadi, ${ }^{2}$ Hamid Jafarzadeh, ${ }^{3}$ Sousan Shalavi, ${ }^{4}$ Jun-Ichiro Kinoshita
}

\section{ABSTRACT}

Introduction: The apical portion of the root canal is very complex and challenging during endodontic treatment. Root canal preparation and obturation to the apical constriction may provide the best prognosis. Incomplete debridement, foramen transportation, and inadequate seal in the apical portion are considered to be responsible for treatment failure. The technique "apical patency" is considered as a way for maintaining the apical part the free of the debris by recapitulation, using a small K-file through the area of the apical foramen. This term was firstly proposed by Buchanan. In this technique, the smallest diameter file is set $1 \mathrm{~mm}$ longer than working length and recapitulated after each instrument to prevent packing of debris in the apical part. Apical patency has been found to be effective in achieving an apical seal with gutta-percha. Teeth prepared with a step back method and with maintained apical patency may show less leakage when obturated with cold lateral condensation technique. Data regarding the effect of apical patency on the healing of periapical tissue are very scarce, and it has been shown that the patency file has detrimental effect on the healing of periapical tissues in animal studies. However, using patency file in endodontic treatment is controversial and further studies are needed. The purpose of this article is to review the effect of using a patency file on the extrusion of root canal contents, the apical seal, postoperative pain, and healing of periapical tissues. Furthermore, the effect of establishing patency on reaching irrigation solutions to the apical portion of the canal and prognosis of root canal treatment are discussed.

\footnotetext{
${ }^{1}$ Iranian Center for Endodontic Research, Research Institute of Dental Sciences, Shaheed Beheshti University of Medical Sciences, Iranian National Elite Foundation, Tehran, Islamic Republic of Iran

${ }^{2}$ Department of Endodontics, Dental Research Center, Faculty of Dentistry, Mashhad University of Medical Sciences, Mashhad Islamic Republic of Iran

${ }^{3}$ Hamedan, Islamic Republic of Iran

${ }^{4}$ Department of Conservative Dentistry, Showa University Dental Hospital, Tokyo, Japan

Corresponding Author: Hamid Jafarzadeh, Department of Endodontics, Dental Research Center, Faculty of Dentistry Mashhad University of Medical Sciences, Mashhad, Islamic Republic of Iran, Phone: +00985138829501, e-mail: jafarzadehbh @mums.ac.ir
}

\section{Clinical significance:}

Keywords: Apical patency, Apical seal, Apical transportation, Postoperative pain, Prognosis.

How to cite this article: Mohammadi Z, Jafarzadeh $\mathrm{H}$, Shalavi $\mathrm{S}$, Kinoshita J-I. Establishing Apical Patency: To be or not to be? J Contemp Dent Pract 2017;18(4):326-329.

\section{Source of support: Nil}

\section{Conflict of interest: None}

\section{INTRODUCTION}

The apical third of the root canal system is very complex and challenging during root canal treatment. Instrumentation and obturation to apical constriction provide the best prognosis. ${ }^{1}$ Incomplete debridement, foramen transportation, and inadequate seal in the apical third are considered to be responsible for root canal failure. ${ }^{2}$ Another controversial issue is to maintain the apical patency or form an apical plug during canal preparation.

According to the American Association of Endodontists, the technique "apical patency" is considered as a way for maintaining the apical portion of the canal free of debris using a small K-file through the apical foramen. ${ }^{3}$ Buchanan ${ }^{4}$ proposed the concept of apical patency for the first time. He defined patency file as a small flexible K-file, which passively moves through the apical constriction without widening the apical constriction. In this technique, the smallest diameter file is set $1 \mathrm{~mm}$ longer than the working length and recapitulated after each instrument to prevent packing of debris in the apical part. According to Cailleteau and Mullaney, ${ }^{5}$ half of the US dental schools taught patency file (42\% used the patency file \#10, 33\% used the file \#15, and 25\% used the file \#20 as a patency file).

\section{EXTRUSION OF ROOT CANAL CONTENTS}

Extrusion of any tissue or material through apical foramen during root canal instrumentation is undesirable because it is responsible for postoperative pain and 
inflammation of periapical tissues. All instrumentation techniques result in extrusion of debris. There is a direct relationship between the amount of extruded debris and the diameter of apical foramen. ${ }^{2,6}$

When apical constriction is not violated by patency file, overfilling was not observed, and greater extrusion was observed when apical constriction is enlarged to \#20 and \#25 file. ${ }^{7}$

According to Souza, ${ }^{8}$ with the help of a patency file, only mechanical objectives are achieved, as its purpose is only to prevent blocking of apical foramen with debris. Patency file does not clean the apical foramen. ${ }^{9}$ However, in necrotic pulp with aperiapical lesion, bacteria may be present beyond the apical constriction. In such cases, instrumentation beyond the apical constriction is desirable from the biological point of view. It has been recommended that in cases of necrotic pulp, instrumentation should be performed up to the apical foramen. Camoes et $\mathrm{al}^{10}$ have worked on extrusion of $\mathrm{NaOCl}$ with and without a patency file. Extrusion was observed in $47 \%$ without patency, $77 \%$ when \#10 K-file was used as a patency file, and $100 \%$ when $\# 15 \mathrm{~K}$-file is used as a patency file. In contrast, Lambrianidis et $\mathrm{al}^{6}$ have observed less periapical extrusion when apical constriction was enlarged. Intentional packing of dentin chips or construction of apical plugs is required in certain clinical situations.

\section{EFFECT ON REACHING IRRIGANT TO THE APICAL THIRD}

Irrigation solutions should have the ability to reach the apical area of the canal with enough contact time and concentration, so that these solutions can kill bacteria, dissolve organic tissues, and eliminate biofilms in the area with complex anatomy. Salzgeber and Brilliant ${ }^{11}$ concluded that Hypaque irrigation solution cannot reach the apical portion of the canal-contained vital tissues. They also showed that if the root canals be prepared to small apical sizes, the irrigation solutions may be detected at the apical area and even in periapical lesions. Root canal preparation techniques used at this instance may possibly push large amounts of solutions and debris through the apical foramen. However, this theory has not been proved in vivo.

An in vivo research on small canals, such as mesial roots of lower molars, buccal roots of upper molars, and both roots of upper first premolars, using a radiopaque solution mixed with $\mathrm{NaOCl}$, showed significantly more irrigation solution after usage of passive ultrasonic irrigation when a small patency file was used during cleaning/ shaping stage compared with those this protocol not be regarded. ${ }^{12}$ In another study with the same method, penetration of irrigants into the apical part of large canals, including distal roots of lower molars with one canal, palatal roots of upper molars, and 19 to $21 \mathrm{~mm}$-length anterior teeth, was studied, and showed higher presence of $\mathrm{NaOCl} /$ solution in the apical area of the canal compared with those patency not established. ${ }^{13}$ According to Tay et al, ${ }^{14}$ weak penetration of the irrigation solution into the apical area may be due to the presence of remaining tissues inside the canal or even presence of gas bubble in the apical portion. Furthermore, Gu et al ${ }^{15}$ suggested that this bubble may become larger due to the action of organic tissues with irrigating materials. On the contrary, Izu et $\mathrm{al}^{16}$ questioned the presence of vapor lock if a highenough flow be applied during canal irrigation and also using an open-ended needle that should be inserted closer to full working length.

Vera et $\mathrm{al}^{17}$ studied the effect of patency file on the presence of large bubbles in the middle and coronal third of the canals in vivo. They showed that these bubbles are not easy to break. Furthermore, when patency file was not applied, bubbles in these parts may be present in $40 \%$ of samples, compared with $25 \%$ when a patency file was used. Although the importance of these bubbles is under question, penetration of irrigation solutions to the apical portion and consistent presence of these bubbles in the upper parts of the canal would decrease the contact of $\mathrm{NaOCl}$ with tissues. Some other studies have shown this vapor lock effect in closed-ended canals, preventing irrigants reach the apical area. ${ }^{18}$ However, some other studies have indicated that some changes in composition of the irrigation solutions by combining the $\mathrm{NaOCl}$ with radiopaque solutions could vary the density and viscosity and also surface contact angle when compared with $\mathrm{NaOCl}$ by itself. $^{16}$

\section{EFFECT ON APICAL SEAL}

Apical patency has been found to be effective in achieving an apical seal with gutta-percha. Teeth prepared with a step back method and with maintained apical patency showed less leakage when obturated with cold lateral condensation technique. ${ }^{19}$ A study by Brady et $\mathrm{al}^{20}$ showed that an apical plug at the apical foramen did not heal periapical tissues and produced periapical infection. Periapical inflammation might be due to the irritating potential of the dentin plugs or microorganisms incorporated into the dentinal chips. It also inhibited the deposition of cementum. They stated that an apical plug between filling material and periapical tissues did not promote healing of the periapical tissues. Favorable healing took place, if there were no intervening plug. The dentinal plug also did not seem to deposit cementum and bone. They intentionally enlarged the apical foramen by overinstrumentation, and a dentin plug was deposited $2 \mathrm{~mm}$ short of the apex. Holland et $\mathrm{al}^{21}$ have observed similar results in their study on tissue reaction to infected 
dentin chips. They did not recommend the use of a dentin plug for infected root canals. Safavi et al, ${ }^{22}$ in their study, have shown inconsistencies in quality and quantity of the apical plug. Minor tissue reaction was observed with dentin chips. They stated that if dentinal chips were contaminated with necrotic tissues and bacteria, the periapical response might be unfavorable.

Yee et $\mathrm{al}^{23}$ as well as ElDeeb et $\mathrm{al}^{24}$ have found that a dentinal plug prevents penetration of dye material, though this was not a constant finding, but varied and was dependent on the quality. Dandakis et $\mathrm{al}^{25}$ also have observed that an apical plug provides effective sealing and prevents dye penetration when cold lateral condensation obturation is used. Using patency files and calcium hydroxide-based sealers, Holland et $\mathrm{al}^{26}$ tried to induce biological apical closure. According to their findings, biological apical closure was achieved with deposition of cementum. They further found that apical patency was essential to achieve biological closure.

\section{EFFECT ON POSTOPERATIVE PAIN}

Patency files may be responsible for periapical tissue irritation, leading to postoperative pain. Arias $\mathrm{et}^{2}{ }^{27}$ have observed postoperative pain in endodontically treated teeth with and without apical patency. Significantly less pain was observed in nonvital teeth when apical patency was maintained. Torabinejad et $\mathrm{al}^{28}$ stated that the apical patency concept may fulfill the mechanical objectives like maintaining working length, but biological objectives, such as complete debridement of the apical part of the canal may not be achieved. According to Souza, ${ }^{8}$ apical patency is intended exclusively to prevent the packing of dentin chips into the apical region that can interfere with the working length.

\section{PATENCY AND RETREATMENT}

Complete removal of the preexisting filling materials from the root canal is a mandatory part for a successful retreatment, ${ }^{29}$ but, by different methods of removal, remaining filling materials have been shown at different levels of the canal; thus, cleaning the apical foramen in retreatment procedures seems to be necessary. However, overinstrumentation during this procedure may force debris and filling materials into the periapical area or even promote transportation of the apical third of canal. ${ }^{29-31}$

According to Lambrianidis et $\mathrm{al}^{6}$ there were significant differences in the amounts of extruded material before and after the enlargement of the apical constriction, with greater extrusion when the constriction remained intact. Tinaz et $\mathrm{al}^{32}$ found more extruded debris with manual preparation techniques in cases the apical patency be used. Deonizio et $\mathrm{al}^{33}$ showed that apical patency cannot affect amount of extruded materials when using ProTaper Rotary System, but it may happen by manual techniques.

\section{PATENCY AND APICAL TRANSPORTATION}

The apical transportation during maintaining the patency has been studied by some researchers. Goldberg and Massone $^{34}$ in an ex vivo study assessed the apical transport induced by \#10 to \#25 K-files, and showed that this transportation occurred in $60 \%$ of the samples. This study also concluded that transportation may be seen even after usage of\#10 K-files.

Furthermore, Gutiérrez et $\mathrm{al}^{35}$ showed that cementum layer may fracture at the apex after penetration of \#15 $\mathrm{K}$-file through the main apical foramen. By contrast, in an ex vivo study, Sanchez et $\mathrm{al}^{36}$ found that when a \#10 reamer or \#8 K-Flexo file be used, no transportation may be seen. Tsesis et al ${ }^{37}$ confirmed this.

\section{HEALING OF THE PERIAPICAL TISSUE}

Data regarding the effect of apical patency on the healing of periapical tissue are very scarce. Holland et $\mathrm{al}^{26}$ showed that patency file has detrimental effect on the healing of periapical tissues in dogs' teeth.

\section{EFFECT ON PROGNOSIS}

Berutti and Castellucci ${ }^{1}$ as well as West et a ${ }^{38}$ claimed that patency file may improve the success rate of endodontic treatment. However, few documents are present to show the effect of apical patency in overall prognosis. $\mathrm{Ng} \mathrm{et} \mathrm{al}^{39}$ stated that patency may be a significant prognostic factor for endodontic treatment.

\section{REFERENCES}

1. Berutti, E.; Castellucci, A. Cleaning and shaping the root canal system. In: Castellucci A, editor. Endodontics. 1st ed., Vol. II. Firenze: IlTridente; 2005. p. 429-457.

2. Buchanan, LS. Cleaning and shaping the root canal system. In: Cohen S, Burns RC, editors. Pathways of the pulp. 5th ed. St. Louis: CV Mosby; 1991. p. 166-192.

3. American Association of Endodontists. Glossary of endodontic terms. 7th ed. Chicago: American Association of Endodontists; 2003.

4. Buchanan LS. Working length and apical patency: the control factors. Endod Rep 1987 Fall-Winter;16-20.

5. Cailleteau JG, Mullaney TP. Prevalence of teaching apical patency and various instrumentation and obturation techniques in United States dental schools. J Endod 1997 Jun;23(6):394-396.

6. Lambrianidis T, Tosounidou E, Tzoanopoulou M. The effect of maintaining apical patency on periapical extrusion. J Endod 2001 Nov;27(11):696-698.

7. Myers GL, Montgomery S. A comparison of weights of debris extruded apically by conventional filing and Canal Master techniques. J Endod 1991 Jun;17(6):275-279. 
8. Souza RA. The importance of apical patency and cleaning of the apical foramen on root canal preparation. Braz Dent J 2006 Feb;17(1):6-9.

9. Siqueira JF. Reaction of periradicular tissues to root canal treatment: benefits and drawbacks. Endod Top 2005 Mar;10(1):123-147.

10. Camoes IC, Salles MR, Fernando MV, Freitas LF, Gomes CC. Relationship between the size of patency file and apical extrusion of sodium hypochlorite. Indian J Dent Res 2009 Oct-Dec;20(4):426-430.

11. Salzgeber RM, Brilliant JD. An in vivo evaluation of the penetration of an irrigating solution in root canals. J Endod 1977 Oct;3(10):394-398.

12. Vera J, Arias A, Romero M. Effect of maintaining apical patency on irrigant penetration into the apical third of root canals when using passive ultrasonic irrigation: an in vivo study. J Endod 2011 Sep;37(9):1276-1278.

13. Vera J, Hernández EM, Romero M, Arias A, van der Sluis LW. Effect of maintaining apical patency on irrigant penetration into the apical two millimeters of large root canals: an in vivo study. J Endod 2012 Oct;38(10):1340-1343.

14. Tay FR, Gu LS, Schoeffel GJ, Wimmer C, Susin L, Zhang K, Arun SN, Kim J, Looney SW, Pashley DH. Effect of vapor lock on root canal debridement by using a side-vented needle for positive-pressure irrigant delivery. J Endod 2010 Apr;36(4):745-750.

15. Gu LS, Kim JR, Ling J, Choi KK, Pashley DH, Tay FR. Review of contemporary irrigant agitation techniques and devices. J Endod 2009 Jun;35(6):791-804.

16. Izu KH, Thomas SJ, Zhang P, Izu AE, Michalek S. Effectiveness of sodium hypochlorite in preventing inoculation of periapical tissues with contaminated patency files. J Endod 2004 Feb;30(2):92-94.

17. Vera J, Arias A, Romero M. Dynamic movement of intracanal gas bubbles during cleaning and shaping procedures: the effect of maintaining apical patency on their presence in the middle and cervical thirds of human root canals - an in vivo study. J Endod 2012 Feb;38(2):200-203.

18. Fazio, R.; Iacono, S. Entrapped gas action for one dimensional models of capillary dynamics. In: Proceedings of the World Congress on Engineering, July 2009, 1-3. Vol. II. London: World Congress of Engineering; 2009.

19. Monsef M, Hamedzadeh K, Soluti A. Effect of apical patency on the apical seal of obturated canals. J Endod 1997 Apr;23(4):253.

20. Brady JE, Himel VT, Weir JC. Periapical response to an apical plug of dentin filings intentionally placed after root canal over instrumentation. J Endod 1985 Aug;11(8):323-329.

21. Holland R, De Souza V, Nery MJ, de Mello W, Bernabé PF, Otoboni Filho JA. Tissue reactions following apical plugging of the root canal with infected dentin chips. A histologic study in dogs' teeth. Oral Surg Oral Med Oral Pathol 1980 Apr;49(4):366-369.

22. Safavi K, Horsted P, Pascon EA, Langeland K. Biological evaluation of the apical dentin chip plug. J Endod 1985 Jan;11(1):18-24.

23. Yee RD, Newton CW, Patterson SS, Swartz ML. The effect of canal preparation on the formation and leakage characteristics of the apical dentin plug. J Endod 1984 Jul;10(7): 308-317.
24. ElDeeb ME, Thuc-Quyen NT, Jensen JR. The dentinal plug: its effect on confining substances to the canal and on the apical seal. J Endod 1983 Sep;9(9):355-359.

25. Dandakis C, Kaliva M, Lambrianidis T, Kosti E. An in vitro comparison of the sealing ability of three endodontic sealers used in canals with iatrogenic enlargement of the apical constriction. J Endod 2005 Mar;31(3):190-193.

26. Holland R, Sant'Anna A Jr, de Souza V, Dezan Junior E, Otoboni Filho JA, Estrada Bernabé PFE, Nery MJ, Murata SS. Influence of apical patency and filling material on healing process of dogs' teeth with vital pulp after root canal therapy. Braz Dent J 2005 Feb;16(1):9-16.

27. Arias A, Azabal M, Hidalgo JJ, de la Macorra JC. Relationship between postendodontic pain, tooth diagnostic factors, and apical patency. J Endod 2009 Feb;35(2):189-192.

28. Torabinejad M, Kettering JD, McGraw JC, Cummings RR, Dwyer TG, Tobias TS. Factors associated with endodontic interappointment emergencies of teeth with necrotic pulps. J Endod 1988 May;14(5):261-266.

29. Schirrmeister JF, Hermanns P, Meyer KM, Goetz F, Hellwig E. Detectability of residual Epiphany and gutta-percha after root canal retreatment using a dental operating microscope and radiographs - an ex vivo study. Int Endod J 2006 Jul;39(7): 558-565.

30. Nica L, Grigorie M, Rusu D, Anghel MM, Didilescu A, Stratul SI. Computer-assisted photomicrographic evaluation of root canal morphology after removal of the filling material during retreatment. Rom J Morphol Embryol 2011 Jan;52 (Suppl 1):443-448.

31. Baratto-Filho F, Leonardi DP, Zielak JC, Vanni JR, SayãoMaia SM, Sousa-Neto MD. Influence of ProTaper finishing files and sodium hypochlorite on cleaning and shaping of mandibuldar central incisors - a histological analysis. J Appl Oral Sci 2009 May-Jun;17(13):229-233.

32. Tinaz AC, Alacam T, Uzun O, Maden M, Kayaoglu G. The effect of disruption of apical constriction on periapical extrusion. J Endod 2005 Jul;31(7):533-535.

33. Deonizio MD,Sydney GB, Batista A, Pontarolo R, Guimarães PR, Gavini G. Influence of apical patency and cleaning of the apical foramen on periapical extrusion in retreatment. Braz Dent J 2013 Sep-Oct;24(5):482-486.

34. Goldberg F, Massone EJ. Patency file and apical transportation: an in vitro study. J Endod 2002 Jul;28(7):510-511.

35. Gutiérrez JH, Brizuela C, Villota E. Human teeth with periapical pathosis after over instrumentation and overfilling of the root canals: a scanning electron microscopic study. Int Endod J 1999 Jan;32(1):40-48.

36. Sanchez JA, Duran-Sindreu F, Matos MA, Carabaño TG, Bellido MM, Castro SM, Cayon MA. Apical transportation created using three different patency instruments. Int Endod J 2010 Jul;43(7):560-564.

37. Tsesis I, Amdor B, Tamse A, Kfir A. The effect of maintaining apical patency on canal transportation. Int Endod J 2008 May;41(5):431-435.

38. West, JD.; Roane, JB.; Goerig, AC. Cleaning and shaping the root canal system. In: Cohen S, Burns RC, editors. Pathways of the pulp. 6th ed. St. Louis: The C.V. Mosby Company; 1994. p. 179.

39. Ng YL, Mann V, Gulabivala K. A prospective study of the factors affecting outcomes of nonsurgical root canal treatment: Part 1: periapical health. Int Endod J 2011 Jul;44(7):583-609. 